\title{
PROCHÁZKA J. - NEČAS, P. Přistupy $k$ tvorbě bezpečnostních a obranných strategií. Banská Bystrica: Belanium. Vydavateĺstvo Univerzity Mateja Bela v Banskej Bystrici, Fakulta politických vied a medzinárodných vzt'ahou, 2020. ISBN: 978-80-557-1656-5. 202 s.
}

\section{Antonín Novotnýa , Richard Stojar ${ }^{\mathrm{b}}$}

Vědecká monografie Přístupy ktvorbě bezpečnostních a obranných strategií, zpracována Josefem Procházkou z Centra bezpečnostních a vojenskostrategických studií Univerzity obrany, Brno a Pavlem Nečasem z Univerzity Mateja Bela, Banská Bystrica se na více jak 200 stranách zabývá přizpůsobováním bezpečnostního systému a systému obrany státu vývoji vnějšího a vnitřního prostředí a př́istupy k tvorbě bezpečnostních a obranných strategií za účelem zajištění bezpečnosti a posílení obranyschopnosti státu.

V českém ale i slovenském prostředí se jedná o skutečně originální počin, který má potenciál přispět ke zvýšení kvality a efektivního zpracování dokumentů obdobného charakteru. Byt' pochopitelně v některých př́padech ani kvalitně zpracované dokumenty nejsou zárukou jejich přijetí či naplnění jejich obsahu.

Autoři si zde dali poměrně ambiciózní cíl, tj. představit a zhodnotit příklady nejlepší praxe pro vytváření relevantních východisek pro vytváření nástrojů bezpečnostní a obranné politiky, dosahování odpovídající úrovně jejich připravenosti i zajištění jejich dlouhodobé udržitelnosti s ohledem na dostupné zdroje. Monografie tak v podstatě představuje soubor doporučení k posílení institucionální adaptace bezpečnostního systému a systému obrany a jejich nástrojů, zejména pak ozbrojených sil. Předkládá zde možnou racionalizaci soustavy strategických dokumentů a přístupů $k$ jejich tvorbě, to vše opřené o kvalitní metodologický rámec umožňující jejich opakované zpracování a hodnocení.

Text je primárně založen na charakteristice strategického rámce a zhodnocení současného stavu problematiky a přináši také komparační analýzu prístupu, pro náš geografický prostor klíčových institucí, NATO a Evropské unie. Tento rámec doplňuje analýza př́stupu dvou vybraných států, Kanady a Norska, které zde mohou posloužit jako př́klad vhodné praxe na národní úrovni. V dalších částech se autoři zabývají konkrétními přistupy $\mathrm{k}$ tvorbě bezpečnostních a obranných strategií a monografie končí poměrně obsáhlou pasáží, ve které rezonují návrhy a doporučení. Součástí této kapitoly je i diskuse a př́padové studie České republiky a Slovenské republiky, obsahující návrhy soustavy strategií.

\footnotetext{
${ }^{a}$ Centre for Security and Military Strategic Studies, University of Defence in Brno. Czech Republic. antonin.novotny@unob.cz. Researcher ID: ABF-8914-2020

${ }^{\mathrm{b}}$ Centre for Security and Military Strategic Studies, University of Defence in Brno. Czech Republic. richard.stojar@unob.cz. Researcher ID: ABF-8988-2020
} 
Důkladný a podrobný popis různých oblastí spojených s tvorbou strategií vyžadoval ze strany autorů patrně nemalé úsilí, které je v knize a textu viditelné. Svědčí o tom i seznam použité literatury a zdrojů, který obsahuje více jak 160 položek. Ke zvýšení účinnosti psaného textu je zde také ve vybraných případech vhodně využito grafické vyjádření. Místo komplikovaného a obtížného popisu návrhu soustavy dokumentů strategického řízení ČR je zde např́klad schéma, který tuto okolnost graficky dostatečně a přehledně osvětluje. Z celkového vyznění monografie lze vysledovat dlouhodobý zájem autorů o tuto problematiku a jejich erudici.

Hlavním cílem autorů, jak je to viditelné v téměř celém textu, bylo zaměřit se na strategickou analýzu prostředí a jeho dopadů na použití a rozvoj ozbrojených sil, formulování polického zadání pro použití a rozvoj ozbrojených sil, stanovení požadavků na schopnosti a v neposlední řadě dlouhodobé strategické plánování a analytickou podporu souvisejících procesů. Současně se však autoři vymezili a deklarovali, že jejich ambicí nebylo $v$ této monografii řešit problémy související se samotnou realizací strategií, tj. především identifikaci vhodných programů rozvoje schopností v procesu střednědobého plánování, problémy spojené s alokací zdrojů na realizaci avizovaných programů a související aktivity spojené s jejich financováním anebo problémy spojené s pořizováním majetku a služeb nebo projektovým řizením. To by také nepochybně přesahovalo vlastní rámec zkoumané a popisované problematiky a je to spíše námět pro prípadnou navazující studii do budoucna.

Lze-li této knize po vlastní obsahové stránce jen máloco vytknout, tak lze zároveň i litovat, že kvalitu vydané monografie zde poněkud snižují některá formální pochybení. Jedná se o občasné stylistické či gramatické chyby, které byly možná zapřičiněny prací v mezinárodním a bilingvním autorském týmu či občasná nepřesnost uvedených citací.

Deklarovaným záměrem autorů bylo vytvořit vhodný metodologický rámec pro tvorbu bezpečnostních a obranných strategických dokumentů v podmínkách nejistoty a navrhnout soubor doporučení pro posílení účinnosti strategického řizení a schopnosti strategické adaptace. Tento záměr byl $v$ představované monografii nepochybně naplněn, byt' problematika i samotný text klade na čtenáře poměrně vysoké nároky. Již $\mathrm{s}$ ohledem na aktuálnost a možnost dlouhodobého využívání této práce $\mathrm{v}$ praxi i teorii ji lze doporučit nejenom odpovědným pracovníkům státní správy napřič rezorty a budoucím zpracovatelům strategických dokumentů, ale rovněž studentům oborů $z$ oblasti bezpečnostních studií či veřejné správy a dalším zájemcům o problematiku, at' již z akademického, či expertního sektoru. 